\title{
HET BIJBELSE SCHEPPINGSVERIHAAL EN DE NATUURWETENSCHAP
}

\author{
A. A. Manten
}

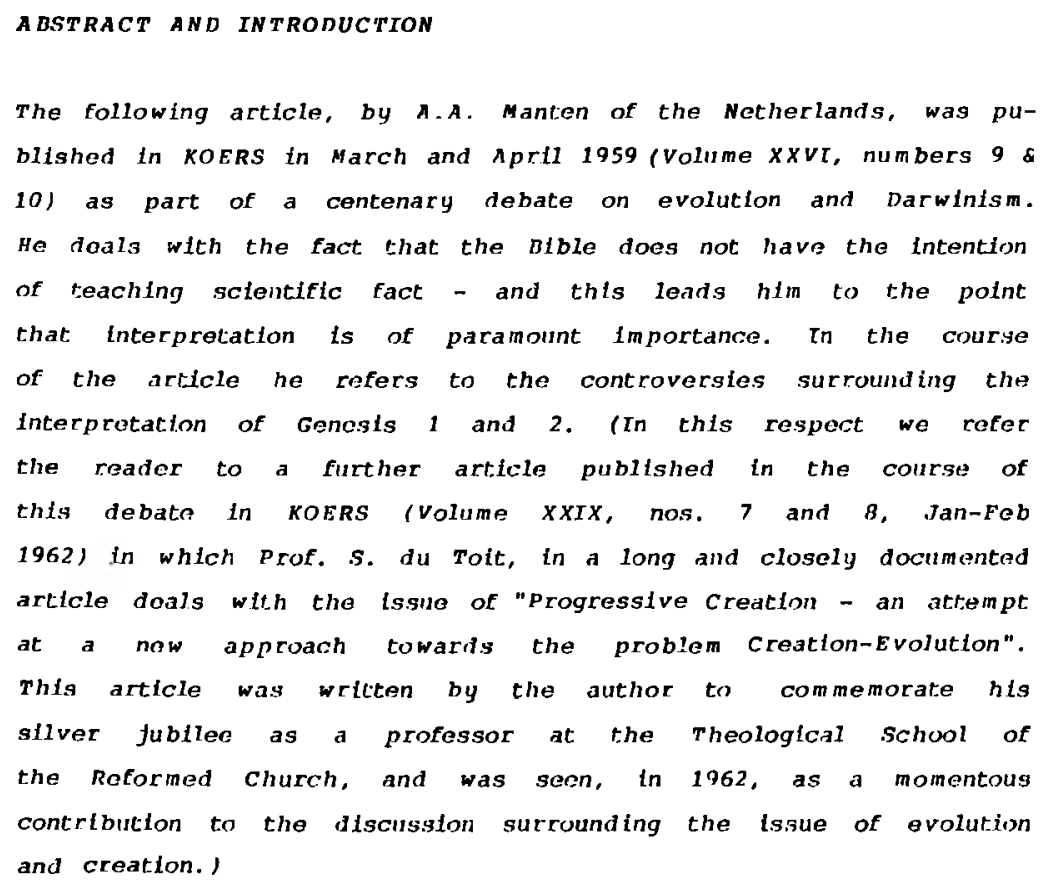


nog wat strijd is, dan gat dat sleclits over bepadile heijzonderheden en zekere voorstellingen en niet meer over liet begrip evolutie als zodanig.

Enorme tegenstand $k$ wall er van het begin af aan ook uit de orthodox christelike kringen, waar men haar nu, honderd jaar later, nog steeds vind. Vele christen-gelovigen menen ook in deze tijd nog, dat indien enige vorm van evolutie aanvaard wordt, dan God uft Zijn heelal wordt uitgeschakeld en de voorstelling van de Bijbel betreffende de herkomst van alle dingen aan flarden wordt gescheurd. In hoeverre is deze opvatting gerechtvaardigd? Bestaat er werkelijk een wezenlijk verschil tussen wat de moderne natuurwetenschap ons leert over het ontstaan der organismen en de inhoud van het bijbelse scheppingsverhaal? Deze vraaj zal het thema zijn van dit en een aantal volgende artikelen.

Vanaf 1858 is er door de natuurwetensichappen nog intensiever dan tevoren gestudeerd op de vraag naar de systematiek en de afstamming van de levende organismen. $0 p$ dit punt wil ik van het begin af aan graag sterke nadruk leggen. Spesiaal theologen zijn er erg op gesteld critiek te oefenen op het werk van Darwill, of soms ook van De Lamarck. Als het gaat om publicaties uit de tegenwoordige tijd, dan botst men veelal op een totale onwetendheid. Men verwacht dat Darwin reeds ineens het gehele evolutie-mechanisine kant en klaar aan ons moet verklaren als een onweerlegbaar feit. Voelt men dat zijn werk daarin niet voor de volle honderd procent is geslaagd, dan wordt de gehele evolutie ter zijde geschoven als een vergezorhte theorie. Vaak heb ik mij afgevraagd warom zo veel gelovigen Darwin's "Origin of species" nlet kunnen lezen met de gedachte dat dit slechts een eerste, gebrekkige poging wat tot formulering van een der meest ultgebreide concepties waarinee de wetenschap ooit heeft te doen gehad. Het is duidelijk dat Darwin niet oniniddellijk naar voren kon koinen met een rapport waarin alle aspecten van dit ontzaglijke probleem kant en klaar, waterdicht zijn uitgewerkt. Zoals ledere eerste poging was ook de zijne nog vol onjuistheden en vraagtekens. 
Wil inell een goed beeld krijgen van wat er reeds allemaal inzake evolutie bekend is, dan zal men nast het werk van Darwin kermis moeten nemen van moderne handboeken over dit onderwerp, zoals bv. "Paläoblologle und Stammesgeschichte" van Abel en "Morphologische Gesetzmassigkeiten der Evolutien" van Sewertsoff.

Het volgende is een uiterst beknopte samenvatting van enkele der belangrijkste fotten warvoor de natuurwetenschappen ons op het ongenblik stellen:

Fossiele overblijfselen van dierlijke oorsprong worden aangetroffen vanaf het Cambrium, dat is een periode, die volgens de geologische tijdrekening ongeveer 550 miljoen jaar geleden begon. In de aardlagen uit deze periode vindt men ineens, vrij abrupt, reeds vertegenwoordigers van bijna alle hoofdgroepen van ongewervelde dieren: eenceligen (Protozoa), sponsen (Porifera), holtedieren (Snidaria), gelede wormen (Annelida), geleedpotigen (Arthropoda), weekdieren (Mollusca) en armpotigen (Brachiopoda). Hieruit moet men dus concluderen, dat we wetenschappelijk over de herkomst van deze hoofdgroepen als zodanig nog zo goed als niets met zekerheid weten.

De gewervelde dieren verschifnen lets later in de geologische geschiedents, maar ook over hun oorspong als groep is vrijwel nlets bekend.

Voor een aantal van de klassen, orden, families, enz., waarin men deze hoofdgroepen $k$ an onderverdelen, geldt hetzelfde als voor- de hoofdgroepen. Ze komen van het begin af aan, voor zover wo daar op het ogenbllk gogovons over bezitten, gecheiden voor. Soms ook is het anders en koinen er binnen een hoofdgroep geleidelijk aan verschillende ondergroepen bij. Dit is bijvoorbeeld het geval bif de gewervelde dieren. De oudste vertegenwoordigers hiervan, de Agnatha of kaaklozen, vinden we in de afzettingen uit een perlode, die ongeveer 400 miljoen Jaar achter ons 1igt, de eerste primitiewe vissen treden voor het eerst op ongeveer 300 miljoen faar geleden, 
de amphibia komen op omstreeks 275 miljoen Jaar geleden, de reptielen ca. 230 miljoen jaar terug, de eerste zoogdieren ongeveer 150 miljoen Jaar geleden, de eerste vogels volgen spoedig daarna.

Kennen we hier wel de overgangsvormen, de verbindingslijnen, die voeren van de ene klasse naar Je andere?

Hier geldt een ja en een nee. Over de herkoinst van de verschillende groepen van vissen weten we nog weinig met absolute zekerheid. Daarentegen is van de $11 \mathrm{jn}$, die loopt van reptielen naar zongdieren vriJ veel bekend. Zeer in bet bijzonder heeft de Zuid Afrikaanse Karroo in dit opzicht enorm veel wardevol materiaal opgeleverd. De fossielen uit dit gebled verschaffen ons een massa aan gegevens ointrent het ontstaan van de zoogdierschedel en het zoogdlergebtt, de oorsprong van warinbloedigheid en het levend ter wereld bregen van de jongen, de ontstaanswijze van het gehoorapparaat, het beken en de bouw der ledematen bij de zoogdieren, enz.

De stap van reptiel naar vogel is niet groot. llet meest wezenlijke verschil tussen deze beide diergroepen is het akticve vilegvermogen, dat men alleen aantreft bij de vogels. Uit de Jura-afzettingen van Zuid-Duitsland nu kent men o.a. twec geslachten van dieren, Archaenpteryx en Archacornis, die zo veel nog of kleine tweevoetige dinosauriers lijken, dat ze verre van onmogelijk als reptielen zouden zijn godetermineerd, ware het niet dat men de afdrukken van vleugels en veren er bij had aangetroffen in de steen, en men lius iniset annemen reeds met vogels te doen te hebben.

Overgangsvormen van de ene klasse naar de andere komen dus ontegenzogilifk voor, al ontbreekt In een flink aantal andere gevallen nog veel van het bewijsmateriaal.

Dat soorten In elkildr kunnen overgaan hehoeft voor een leder, die ook maar fets met de organische natuurwetenschappen met de hoogte is, in het gehenl geen betong ineer. Eenmaal getrokken grenzen tussen twee soorten kunnen door nleuwe vondsten worden 
overschreden en het "soortbegrip" is één van de grote probleme uit de moderne biologie en palaeontologie. Idere onderzoeker heeft weliraast zijn eigen definitie van wat een "soort" is en de soort van de een is de ondersoort of het geslacht van de ander. Zoals niet éen mens precies gelljk is aan een ander (hoewel alle mensen, die tegenwoordig op aarde leven behoren tot éen en de zelfde soort), zo is ook vrijwel geen een dier gelijk aan een ander.

Maar wat nu? Moeten de christenen dit alles zo maar aanvaarden?

Eigenlfjk kan het antwoord hierop kort zijn, nanelijk Ja. God vraagt nooit van ons welke feiten ook te loochenen of te negeren. Integendeel, de christen-onderzoeker behoort meer dan welk ander wetenscha!smens ook eerbied te heiben voor de feiten. De Nederlandse geloofsbelijdenis spreekt over de natuur als een "schoon bock, in hetwelk alle schepselen, grote en kleine, gelijk als letters zijn, die ons de onzienlijke dingen Gods geven te aanschouwer, namelijk zijn ceuwige kracht en Goddelijkheid". Door niet te aanvaarjen wat de natuur ons als feiten leert, makkt de mens zich dus schuldig aan ongeloof. Terecht merkt Prof. Sizoo inzake het wetenschappelijk onderzoek op, dat "de kennis waartoe het leiden zal, waarheidswaarde bezit, dat mogen wij vertrouwen, juist omdat Gods openbaring ons leert, dat de wereld geen chaos is, dat zij niet contigent is, maar een geordent geheel, gegrond in Gods wijsheids, product van Zijn overleg en besluit." 1 Daarom het ik ook ernstige bezwaren tegen de zinsnede in "die Kerkblad" van 3 September 1958, waarin wordt gezegd: "Ons moet volgens hulle (ech aantal Zuid Afrikaanse natuuronderzoekers) nie ons afkoms terugvoer na die skepping van die mens deur God na sy beeld en gelykenis nie, maar ons moet in grotte die kopbene van ons voursate gaan soek, toegerus met lange onderkade en groot-oupas met stewige slagtande. Hierdie dinge word onder die dekmantel van "wetenschap" by vernuwing aan die grout klok gehang." God verbied ons nergens om in grotten te gaan zoeken. Integendeel. Ook dit valt onder het "onderzoekt alle dingen". De opgravingen nar aapmensen in de grolten van 
Transvaal zijn even belangrijk als de arcraeologische onderzoekingen in het Heilige Land en evenals deze kunnen zij ons we ook dat aanvaarden als een bepaalde bijbelgedeelten gegeven moet worden. Als we in de natuur duidelijke bewijzen vinden, dat er vroeger aapmensen op onze aarde hebben geleefd, dan moeten we ook dat aanvaarden als een bepaalde openbaring van God, en we mogen daarbif in volle vertrouwen aannemen, dat $\mathrm{Hij}$ ons ook hierin niet zal kunnen of willen bedriegen. Het is 20, aldus merkt Ridd, rbos terecht op, "dat al mag de natuurwetenschap op geen enkel punt decreteren hoe de Schrift uitgelegd moeten worden, de beschouwingen die de natuurwetenschap voordraagt, wel aanleiding kunnen zijn, dat bif een bepaalde kwestie de vraag moet worden gesteld: Is het ook mogelijk, dat wat wij uit de Schrift meenden te kunnen en moeten afleiden, niet metterdaad door de Schrift geleerd wordt, maar dat we de betrokken Schriftgegevens anders moeten exegetiseren?"

Men dient in de theologie een duidelifk onderscheld te maken tussen de Bijbel zelf en de exegese, die van haar inhoud gegeven wordt.

Wat we in de Bijbel meegedeeld vinden is, ik citeer weer de Nederlandse geloofsbelydenis, ons gegeven "voor hellig en canoniek, om ons geloof daarnaar te reguleren."

Geheel hiernaast staat de exegese. De exegese is iets menselijks. Zij behoort als theoretische wetenschap de exacte mogelijkheden aan te geven, die een bepaalde tekst wat betref zijn uitleg biedt. Binnen deze mogelijkheden (want dat kunnen er op een gegeven ogenblik meerdere lijken te zifn) ligt hetgeen de tekst wil zeggen. Deze exegese is dus iets menselijks en als zodanig, zulks in tegenstelling tot de bijbel zelf, zeker niet onfellbaar.

Passen we dit nu toe op het scheppingsverhaal. Gaan we de geschiedenis van de exegese van Genesis 1 na, dan biljkt dat ook hlervoor in de loop der eeuwen meerdere vitlegen gegeven zijn. Maar nog sterker: Vele eeuwen voor er in de natuurwetenschappen van evolutie gesproken werd, gaf Augustinus 
reeds een interpretatie van het scheppingsverhad, die volledig met een geleidelfjke ontwikkeling van al liet lavende rekening hield. Volgens deze kerkvader waren alle dingen in het beghn tegelijk door God geschapen en wel in overeensteming met de Goddelijke ideeën. Bij de schepping werden deze idceën oingezet in klemen en oorzaken. Door een samenspel hiervan kon zich het geschapene in de tijd ontwikkelen. Dit betekent, volgens Augustinus, niet dat alle dingen, die wij nu in de werkelijkheid kennen, reeds meteen na de schepping in volledige mate aanwezig waren. zij waren er natuurlijk wel, maar meestal nog slechts in potentie, in konkrete kiemvorm. Onder de leiding van de Goddelijke Voorzienigheld kunnen zij zich in de loop van de tijd ontplooien vanuit de reeds gegeven kiemen en oorzaken. Augustinus acht dit te voorschijn komen een natuurlijk proces, dat kan plaats vinden zonder een bovennatuurlijk ingrijpen van God. ${ }^{3}$

Deze visie op het scheppingsverhaal is dus een geheel andere, dan die, welke gedurende de negentiende en de eerste helft van deze eeuw door velen word adngehangen en waardoor de (schijubare) botsing wetenschap - gelonf ontstond. Het essentiële punt in deze beschouwing is, dat de soorten konstant en stuk voor stuk door Gods geschapen zijn. Na het voorgaande is het al enigermate duidelijk dat het scheppingsverhaal dat helemaal niet zo zegt, anders zou Augustinus dat er zonder twijfel ook reeds in gelezen moeten hebben. Het scheppingsverhaal kan dit ook niet zeggen, want het begrip soort, zoals wij dat hanteren, werd pas in de tijd van Linnaeus, omstreeks 1650 voor het eerst gedefinieerd, en het was dus aan Augustinus en wel helemaal aan de schrijuer van het Genesisverhaal, nog volledig onbekend.

Onder invloed van de biologie ging men er in de zeventiendeachttlende eeuw toe over het begrip "aard" of "wezen", warvan in het scheppingsverhaal sprake is ("gewas, dat naar zijn aard vruchten draagt". "gevleugeld gevogelte naar zijn aard", "wild gedierte naar hun aard", om maar enkele voorbeelden te noemen) te vereenzelvigen met "soort", zoals ook tegenwoordig de Zuid Afrikaanse bijbelvertaling nog doet, als zij schrijft, 


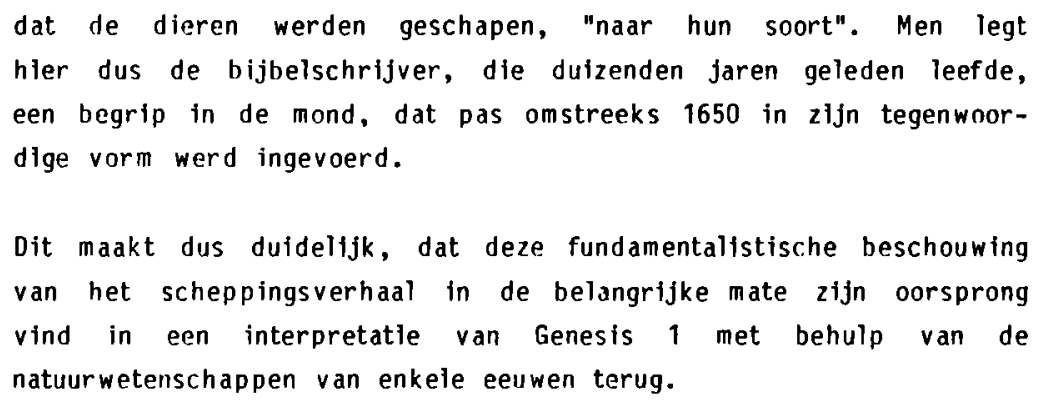

"Deze constatering is reeds daarom merkwaardig", zo merkt Prof. Lever" daarbif op, "daar het fundamentalisme andersdenkende binnen de christelijke kring verwijt dat zij hun denkbeelden ontlenen aan de natuurwetenschap en reeds in meerdere of mindere mate door de materialistische tendenzen hierin zijn meegezogen.

In feite is het 20 , dat het fundamentalisme onbewust de moderne natuurwetenschap spiegelt tegen die $v$ an enkele eeuwen terug en de laatste canoniseert met Bifbeiteksten."

Wat betreft de bijbelse scheppingsgeschiedenis, $k$ an geen tegenstelling bestaan tussen geloof en natuurwetenschap, omdat de bijbel niet de bedoeling heeft ons naturwetenschappelijke feften te leren.

Maar nu doet zich als vanzelfsprekend de vraag voor, hoe wij lit eerste bijbelhoofdstuk dan hebben te zfen, en welke betekenis zij in deze tijd nog voor ons heeft. Hierbij komt dus opnieuw het punt interpretitie aan de orde, m.a.w. een menselijke, gebrekkige benadering van de bijbel, zoals ook de opvatting van een schepping in $6 \times 21$ uur een menselifke interpretatie van het eerste bijbelhoofdstuk was.

Wanneer we in het volgende een eigen visie geven op het scheppingsverhaal, is dit dan ook steeds in het besef dat zij geenszins alleenrecht van bestaan heeft. Ons streven is echter steeds aan de bedoeling van het bijbelwoord zoveel mogelijk recht 
te doen, zonder daarbij bepaalde naturwetenschappelijke gegevens, natuurwetenschappelijke feiten te willen wegkritiseren. Want, zoals reeds eerder opgemerkt, de bijbel, God vraagt nooit van ons feiten te loochenen of te negeren.

De bijbel opent met de inachtige woorden: "In den beginne schiep God de hemel en de aarde." Het eerste wat wij lezen is dus de pradiking van God over zijn souverein recht op het leven der mensen. Hierin liggen ontzaglijke konsekwenties voor het leven van elk kreatuur besloten. God is begonnen met ons, Israels God, die de Kerk als de Vader van Jezus Christus belijdt, is met ons begonnen. God is niet alleen diegene, die handelend optreedt in de geschiedenis van Israel om zo "alle geslachten der aarde te zegenen" en naar Zijn uiteindelijk Doel te leiden, maar $H i j$ is ook de Schepper der wereld, om daarin de mensen, als Zijn kinderen, te doen wonen, om hen, met wie God omgang en gemeenschap hebben wil, te lefden naar Zijn Einddoel.

Het is geen geschiedschrijving, warmee we hier te doen hebben, maar profetie, getuigenis van het geloof. De schepping is "kiene historische Geschichte", d.w.z. "sie entzieht sich aller historischen Beobachtung und Berichterstaatung" ${ }^{5}$. We krijgen geen notulen te lezen, hoc het scheppingsgebeuren zich precies van moment tot moment voltrokken heeft, maar de prediking, dat de God, die Israel heeft uitverkoren, geroepen, verlost en geleid, gestraft als dit nodig was, maar toch telkens weer opnieuw verlost als Zijn volk, niet alleen de God van Israel is, maar ook de Schepper van alles wat buiten Hem bestaat.

De Bijbel eindigt met het majestieuze boek der Openbaring, waarin ons in beeldende vorm een blik wordt gegund in de toekomst. Openbaring is beeldspraak. Niemand van u zal geneigd zijn haar inhoud volkomen letterlijk te nemen.

Als Christus tijdens Zijn rondwandelingen op aarde de scharen toespreekt, die Hem volgen, dan is dat vrijwel steeds in 
de vorm van gelijkentssen, in de vorm van beeldspraak. Hyj spreekt 20 , dat het publiek Hem $z a l$ kunnen verstaan. $H i j$ gebruikt gecn wetenschappelijke voorbeelden om Zijn bedoelfngen te verduidelijken, maar past zich zo dicht mogelijk aan bij het ailedaagse leven. Geen beter preek over de liefde van God dan de gelfjkenis van de verloren zoon; geen duidelfjker voorbeelde van naastenliefde dan het verhaal van de barmhartige Samaritaan.

De Bijbel begint met het scheppingsverhaal. Niemand was er bij toen de schepping plaats vond. Wat de Bijbel over de schepping zegt, is openbaring van God. Is er een wezenlifk verschil tussen het spreken van God tot de mens wanneer dat is door de persoon van Christus, of door middel van de inspiratie van het Genesisverhaal aan de bijbelschrijver? ook in het. scheppingsverhaal gaat het om de principiële waarheden die vorr het geloofsleven van de mens van belang zijn, niet om een stik natuurwetenschap. Daarom wordt wat gezegd wordt gezegd in een eenvoudige, voor de mens bevattelljke vorm.

Het scheppingverhaal is een prediking; een konklusie vanuit het geloof. Geen op verstandelijke konkiusies berustende overtuiging, dat er wel "wat" moetzfjn, een "wat", dat men dan God, schepper, voorzienigheid noemt, zoals in het primitiewe, en moderne, hefdendom. Zo echter maakt de mens voor zichzelf een schepper. In de Bijbel gaat het nfet om een zo zelf gekonstrueerd godsbeeld. Het is nict 20 , dat ook de oude bijbelschrijuers, op grond van hun natuurbeschouwingen tot de overtuiging kwamen, dat er wel "wat" moest zijn en toen als vanzelfsprekend hun verhaal met deze God en Schepper zijn hegonnen. Integendeall ZfJ zijn niet begonnen, maar het is Jufst God, die begonnen is. God Is in de Bijbel allereerst de Handelende. Hiervan getuigen ook le bijbelschrifvers. Zij zijn geen fllosofen, die hun opinies over het ontstaan der wereld te boek hebben willen stellen, doch zij geven slechts een getuigenis, "zo heeft God ons aangesproken, dit hebben wif gehoord, beleefd, ervaren". $0 \mathrm{~m}$ dit alles voor de mens bevattelijk te maken, is het in anthropomorfistische voorstellingswijze gegoten. Duldelijk is dit bijvoorbeeld vooral 
in Genesis 2:2v. als gesproken wordt over het rusten van God; er mag niet uit worden afgeleid, dat God zich moest inspannen oin de wereld te scheppen.

Zo gezien is het ook helemal niet zo vanzelfsprekend, dat de eerste hoofdstukken van de Bijbel aan de schepping zijn gewijd. Want immers: de geschiedenis der schepping, zoals wij die vinden in Genesis 1 en 2 mag alleen worden verstaan vanuit de hellsgeschfedenis dai betekent dus: vanuit Jezus Christus, omdat de hele Bijbel profeterend spreekt, afschaduwend van Jezus Christus, ook waneer hij spreekt van de Schepper, de schepping en het schepsel. De Bijbel is ên geheel. De scheppingsguschledenis is nlets anders dan terugwadrs gerichte profotie van do hollsgeschleuenis. 0ok dit bijbelgedeelte hebben we daarom te zien vanuit christus. In Christus leren we het subject van de schepping kenne. Jezus Christus is de enige sleutel, die het geheimenis der schepping voor ons kan ontsluiten. Het geloof in Hem voert altijd tot een aktief scheppingsgeloof. Het is vooral de verdienste van Karl Barth op deze zijde $v a n$ de schepping duidelijker de adndacht te hebben gevestigd. Door Christus wordt het geluof in God als de Schepper van hemel en aarde levend, en in genade erkend. Alleen door een levend geloof, door Jezus Christus is ons verwekt, wordt de geweidige betekenis $v$ an de schepping gezien en beleefd.

\section{IN HET BEGIN SCHIEP GOD ...}

In het begin. Wanneer was dat? Ongeveer vier duizend jaar voor de geboorte van Christus? Vele miljoenen jarell eerder nog? Daarop geeft de bijbelschrijver ons geen antwoord. Hij is geen notulen-schrijver, mad een profect, een geloofsgetuige. Hij beschrijft niet de zuiver historische gang van het scheppingsgebeuren, alsof $h i j$ er zelf bif was geweest. Hij geeft ons een getulgenis van de grote liefde van God. God maakt een begin, de eerste "steen" voor de geschledenis van het genadeverbond wordt gelegd. 
De Bijbel zegt ans dat de wereld een begin heeft. Alleen God

is eeuwig. Al het andere is kreatuur, schepping, door God

in en met de tijd in het aanzijn geroepen. Al wat op ons $z o$ ' $h$ diepe indruk $k$ an maken, deelt in deze kreatuurlijkheid.

"God schiep...", tegenover Zijn universele Scheppersmacht worden alle dingen in hun pure kreatuurlijkheid onthuld. De angst, die de natuur met haar diepten kan oproepen, wordt overkoepeld door de heerlijkhefd van de Schepper.

In de fllosofie van Plato en Aristoteles wordt ervan uit gegaan dat de wereld eeuwig is, van een begin $k a n$ bij hen geen sprake zijn. Dok in vele meer of minder primitieve godsdiensten is er van alle eeuwigheid af aan "iets", een oerruimte, oerelementen, de chaos of wat ook.

In de Germaanse scheppingsmythe wordt gesproken over een oertijd, waarin er een lege ruimte bestond, Ginnungagap genoemd. Boven deze rutmte ontmoetten elkaar de vonken van Muspelheim en de kille nevels van Niflhelm, uit wier aanraking de reus Ymir ontstond. De goden odin, Vilje en Ve doodden Ymir en maakten uit zijn lichaam de aarde, terwijl zij uit een paar bomen, die zij langs het strand vonden, de eerste twee mensen vormden.

In het Babylonische scheppingsverhaal bestond $e r$ in het begin niets anders dan een vloeibare inassa: de chaos, waarin zich twee monsters bevonden, een mannelijke en een vrouwelijke, Apsue en Tiamat. Jit deze twee monsters komen de goden voort. Hier is er dus eerst de chaos en daarna komen pas de goden, die bijgevolg ook een "begin" hebben. De goden willen nu uit de chaos een kosmos inaken, dus de wereld scheppen. Apsoe en Tiamat verzetten zich hiertegen. Er ontstaan een geweldige strijd tussen de beide monsters en de eerste goden; de laatsten kunnen echter de overwinning niet behalen. Daarop biedt Mardoek, én der goden, aan het monster Tiamat te verslaan, op voorwaarde dat hij na zijn overwinning tot oppergod verheven wordt. Men accepteert zijn voorstel. Mardoek verslaat 
Tiamat en splijt haar in twee stukken. Uit het ene deel maakt hij de hemel, uit het andere de aarde, welke hij daarna van planten, dieren en mensen voorziet.

In de oud-Griekse godsdienst was er de eeuwigheid van Ga of Gala, Moeder Aarde. Uit haar komt alle leven en alle leven keert ook weer tot haar terug. De vruchtbaarheid komt van Vader Hemel, die met Moeder Aarde in een "heilig huwelijk" treedt. Uit dit huwelfjk wordt alle vruchtbaarheid geboren.

Het Shinto, de volksgodsdtenst van Japan, leert, dat de hemel en de aarde in het begin niet gescheiden waren. De aardse en hemelse elementen vormden samen een chaotische massa, vergelijkbaar met een et. Hiervan werd het heldere zuivere gedeelte fijn over de ruimte verdeeld en vormde zo de hemel. Het $z w a a r d e r e$ en grovere deel bezonk en werd tot de aarde. Tussen hemel en aarde werden hierna de gode geschapen. Uit het huwelijk van twee van deze goden ontspruiten in de oceaan de eflanden van de Japanse archipel, alsmede ook nog verschillende andere goden.

Tegenover deze op velerlei plaatsen voorkoinende voorstelling nu, van de schepping als een bepaalde vormgeving van een aanwezige materie of van evolutle of transformatie $v a n$ lets dat er al was voor dat God of de goden er waren, stelt de Bifbel nu de eeuwigheid van God. God is de prima causa, de eerste oorzaak van Wie alles afkomstig is. Hij verwerpt deze gedachte aan een ongeordende stof, die altoos heeft bestaan, en spreekt van God, die al het "niet zijnde tot aanzijn roept" ${ }^{6}$, die de Schepper is van alles wat er buiten Hem bestat. Hemel en aarde worden hier niet uit God geboren. In dat geval zouden zij een goddelijk karakter bezitten of althans een goddelfjke kern. Neen: zij worden Joor God in wording geroepen. God alleen is God, al het andere is slechts kreatuur. Daarom laat God de auteur van het Genesisverhaal de ultspraak van vers 1 aan vers 2 doen voorafgaan. 
"... de hemele en de aarde ..."

De hemel is het gebied van God, de Hogen en de Verhevene ${ }^{7}$, onzichtbaar en onberefkbaar voor de mens, ten teken, dat God gans anders is. De aarde is eveneens gebfed van God, maar wordt door Hem beschikbaar gesteld als woonplaats voor de mens, wordt voor de mens geschapen. Hemel en aarde, boven en beneden, de woonplaats van God en van de mens, zij zijn beide geschapen. "Ik ben de eerste, ook ben Ik de laatste; ook heeft mijn hand de aarde gegrondvest en mijn rechterhand heeft de hemelen uitgebreld" ${ }^{\circ}$ Hemel en aarde, twee verschillende dingen, als teken van het absolute verschil tussen God en de mens, maar beide staande op dezelfde noemer: kreatuur, dus toch ook een zekere eenheid als beeld van de genadige verbondenheid tussen God en de mensen.

"De aarde nu was woest en ledig, de duisternis lag op de vloed, en dé Geest Gods zweefde over de waterren."

Over dit vers, Genesis 1:2, zijn doorde theologen al heel wat gevechten gevoerd. We zullen ons hlerin niet mengen, doch slechts enkele opmerkingen over deze tekst maken. De aarde wordt hier getekend als een chaos, woest, leeg en in volkoinen duisternis gehuld, zonder toekomst. Er zijn allerlei krachiten aan het werk, die een leven van dier en mens onmogelfjk maken. En daarboven swevend de Geest van God, als een vogel die zich wil neerzetten om te broeden, maar nergens een rustpunt $k$ an vinden.

De betekenis van dit gedeeite kan mogelijk zijn een beschrijuing van de aarde, zoals die er uit zou zien als zij ntet werd in stand gehouden door de genade en trouw van God, de Schepper. Zonder het scheppende en in stand houdende werk van God, de Vader, zou de aarde worden tht een vormeloos en hopeloos geheel, waarmee zelfs de Geest van God niets meer weet aan te vangen. Zo zou de wereld zijn als God zijn bemoeienis met haar zou beëIndigen. Von $\mathrm{Rad}^{9}$ spreekt in dit verband van een "Moglichkeit, die immer gegeben ist" ${ }^{10}$. Opvallend 
is hierbij, dat inzake sominige plaatsen, als bijv. Job $26: 7$ 12v. vrijwel niet vast te stellen is, of gesproken wordt over Gods doen bij de schepping, dan wel over de voortdurende werkzaainheid van God. Ook dit hangt samen met het feit, dat als God, die bij de schepping de aarde Lewoonbaar gemaakt heeft, niet bij voortduur de inachten, die het leven onmogelijk maken, zou bedwingen, de aarde opnfeuw tot komplete chaos zou terugvallen. Doch door Christus is dat geen werkelijkheid geworden. Door de mens zou zij geworden zijn tot een chaos, los van God. Maar Christus heeft de scheppingsbedervende, woestheid- en duisternis-stichtende machten overwonnen. Door Hem gaat de schepping nu een grote toekomst tegemoet. Hij zal de heilsgeschiedenis van God met inens en wereld, welke bij de schepping begon, ook voltooien ${ }^{11}$. Dat God eenmaal zijn Woord heeft gesproken over de "woestheid en ledigheid" is ons een garantie, dat die "woestheid en ledigheid" nimmer zal terugkeren.

"En God zelde ..."

Hier begint God met het in aanzijn roepen $v$ an een andere werkelijkheid, van een geschapen werkelijkheid, naast Zijn eeuwige Werkelijkheid. Nog is Hij alleen. Doch sprekende

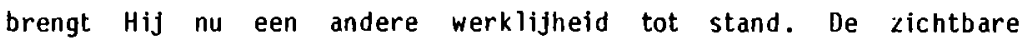
en onzichtbare dingen worden opgeroepen. Zij worden opgeroepen zonder dat zij er waren en zij zijn er. God "sprak en het was er. Hij gebood en het stond er"12. Hier begint het spreken van God, dat aan de hele verdere geschiedenis richting zal geven en deze naar de Toekomst $z d l$ leiden. "In den beginne was het woord en het Woord wat bij God en het Woord was God. Dit was in den beginne bij God. Alle dingen zijn door het Woord geworden en zonder dit is geen ding geworden, dat geworden is" ${ }^{13}$. Het orde-scheppende, richting-gevende en naar het Doel-leldende Woord van God staat vour ons in Jezus Christus, die het Woord is. Hij kwam "tot het Zijne"14 In een wereld die door Hem geworden $1 \mathrm{~s}^{15}$. De wereld is geschapen dour het Woord. Dat Woord is Jezus Christus. Daaroin ook is de wereld en wij met ildar, Zijn eigendom. 


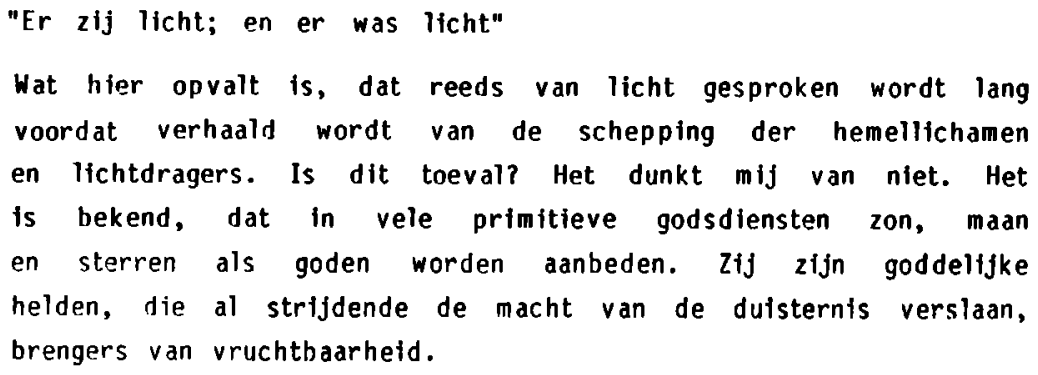


en er luchtig bif lopen. Wij twintigste eeuwers aanbidden de zon wel niet, maar de zun en de warme lucht fleuren ons toch zowel uiterlijk als innerlijk geducht op, terwijl de Bijbel eigenlijk nog inaar weinig inet ons weet te beginnen.

Wat stelt Genesis 1 hier nu tegen over? De prediking dat zon, maan, sterren en planeten niets goddelijks aan zich hebben, maar met al het andere slechts tot een geschapen realiteit behoren. Ja zelfs dat, ais God dat w1l, er ook licht kan zijn zonder al deze hemellichamell. Zon, inaan en sterren hebben een taak te vervullen in once wereld, maar geen onmisbare ${ }^{16}$. Zij dienen mede als getuigenis van het wezen van de Schepper. als heenwijzing naar Hem, die dit alles schiep, en die in de persoon van Christus zich midden in de duisternis van het mensdom begaf, tot een "licht tot openbaring voor de heidenen en heerlijkheid voor uw volk Israel" 17

"En God zag, dat het licht goed was ..."

Het licht is goed in Gods ogen. Niet ondat het zoveel nuttige efgenschappen bezit, maar ondat Hij er iets in terug vindt van Zijn eigen wezen. Zoals ook bij ons inensen een goed werkstuk altijd iets weergeeft van de geest van de maker en wi,j juist als ons beste werk dat beschouwen, waarin wij onszelf het meeste terugvinden, 20 ook kan hier gezegd worden, dat het licht goed is. Want het is eell weerspiegeling van het Licht, dat de duistere macht van de zonde zal doen verdwijnenen. Daarom is het licht qoed.

"... en God makte scheiding tussen licht en de duisternis."

Naast het ${ }^{*}$ licht ontmoeten we nu ook de duisternis. Maar er wordt niet gezegd, dat God de duisternis schept, evenals het licht. Integendeel! God scheidt juist de duisternis van het licht. Die twee horen niet bijeen. Het licht is goed, de duisternis niet. Zij worden uiteen gehaald, zoals door het Kruis de duisternis der anti-goddelijke inachten wordt op $\angle$ ij geschoven door het Licht der wereld.

Het is God, die licht en duisternis scheldt. Dit zegt ons tevens 
dat Hij ook macht heeft over de duisternis, over de duistere machten, hoe sterk die ook mogen lifken. Dit weten kan de gelovige blij maken, moet hein blif maken. Iedereen leest de tekst: "Vreest niet, geloof alleen!" Dan knikt men eens $v a n$ ja en ... gaat weer door met vrezen en twijfelen. Het is langzaain maar zeker bijna nurmaal geworden, dat bij moelte en tegensiag het geloof het ontgelden moet. De duisternis is ook zo sterk. Vroeger, ja vroeger, toen was het geloof er oin bergen te verzetten en om er inuren mee over te springen. Maar dat was vroeger, toen onze jaartelling pas begonnen was. Tegenwoordig weet men wel dat bergen verzetten onmogenlijk is en over een muur kom je alleen maar met een ladder. Doch "God maakte schelding tussen het licht en de duisternis". Hebt dus goede moed. Alle moeite en tegenslag is van tijdelijke aard. Wel kan de duisternis de aarde bedekken, doch "uw licht koint en de heerijkheld des Heren gaat over $u$ op"18 en "de Here zal u tot een eeuwig licht zifn"19.

"En God noende het licht dag, en de duisternis noemde Hif nacht."

Het licht wordt door God dag genoeind. Wif mogen hier aan het woord "dag" geen bepaalde vaste tijdseenheid verbinden, noch die van twaalf uur, noch die van "vele miljoenen jaren." ook voordat de lichten waren gesteld, werd reeds gesproken van lag en nachts. Blijkt hieruit niet te meer, dat de schrijuer niet aan dagen in de letterlijke zin heeft gedacht? Het woord "dag" wordt door hem op een weinig exacte wifze gebruikt. Eerst duidt het een periode aan dat het licht is, vervolgens een etinaai. Het heeft geen zin in de scheppingsprediking het woord "dag" op te vatten als een afgemeten periode.

In dit verband is het goed er nog eens weer op te wijzen, dat de scheppingsgeschiedenis geon historische geschiedenis is, in de zin die de moderne geschledeniswetenschap hieraan gewoon is te hecten. Wie historie beschrijft, kan de samenhang duidelijk maken met andere, gelijksoortige historie. De geschiedenis van de schepping echter is voor ons mensen nfet begrijpelijk, en evenmin te vergelijken met andere, gelljksoortige geschiedenis. 
We hebben hier te maken met het onbegrijpelijke werk van God, dat valt buiten elke wet van analogie en correlatie. Het scheppingsverhaal is als zodanig een praehistorische, een voorhistorische geschiedents.

God noeinde het licht Jag en de duisternis nacht. Licht en duisternis krijgen leder dus hun plaats toegewezen. De dag is de tijdseenheid, die voor ons bestemd is, de tijd om te leven. De dag is de tijd van het licht en het licht is een getuigenis van de goedheid van God. Frgo is dus de tijd om te leven een getuigents $v$ an de goedheid Gods.

De duistenis krijgt ook haar plaats. De nacht is niet de tijd waarin wij leven en werken. De nacht, dat wil dus zeggen de duisternis (chaos, zonde, dood) bedreigt de dag (het goede leven) en maakt haar vol zorg. Maar dat God de duisternis plaats en naain geeft wil zeggen, dat God ook heerschappij heeft over de dulsternis. Ook de duisternis bestaat slechts bif de wil van God, maar ze behoort tot Gods "vreemde" werken".0

De nacht mag lang zijn, "de Here is mijn licht en mijn heil, voor wie zou ik vrezen? 21 God geeft de duisternis haar plaats. Doch slechts tijdelijk. Wallt Jezus Christus heeft de duisternis overwonnen. Daaroin kan er van de nieuwe heinel en de nleuwe aarde ook gezegd worden "er zal geen nacht ineer zijn"22.

"Toen was het avond geweest en het was morgen geweest: de eerste dag."

De eerste scheppingsfase is voltooid. Naast de eeuwige Werklijkheid van God is er nu door Zijn Woord een tweede werklijkheid, een creatuurlijke, geschapen in die Tijd. Het werd avond en het werd morgen. De dagen nemen hun loop. De heilsgeschiedenis neemte een aanvang.

\section{Voetnoten}

1 G.J. Sizzo in Sizoo e.a. "De ouderdom der aarde", 3e druk, 1953, p. 10 . 
2 Dr. Nic H. Ridderbos "Beschouwingen over Genesis 1", Vrije Universiteit Amsterdam, 1954, p. 12. Vergelijk ook K. Schilder "Een hoorustoot tegen Assen?" 1928, p. 44 v.

3 Zie nok Prof. J. Lever "Creatie en Evolutie". Wageningen 1956.

4 J. Levern "Creatie en Evolutie", 1956, p. 12.

5 K. Barth "Die Kirchliche Dogmatiek" III, I, 1945, pag. 44, 48 vv.

6 Romeinen 4: 17.

7 Jesaja 67: 15.

8 Jesaja 18: 12.

9 G. vin Rail "I)as Alte Testament Deutsch" II" ${ }^{3}, 1953,38$.

$10 \mathrm{Er}$ mogn hier verwezen worden naar teks ten als Job 38: 8vv., Psalin 16: 3 v., Psalm 93: 3.

11 openbaring 21: 1-8.

12 Psaiın 33: 9.

13 Johannes 1: 1-3.

14 Johannes $1: 11$.

15 Johannes $1: 10$.

16 ook op andere plaatsen in de Bijbel vinden we de voorstelling, dat de mens de hemellichainen niet nodig heeft om licht te ontvangen, zle Jesaja 60:19v.; Openbaring 21:23; Openbaring 22:5.

17 Lucas 2:32. 
18 Jesaja $60: 1-3$.

19 Id. vers 20.

20 Jesaja 28:21.

21 Psalm 27:1

22 0 penbaring 22:5.

(Reformasie: (Gereformeerde Teologiese Studie.) 